\title{
The chicken and the Orphean egg: On the function of meaning and the meaning of function
}

\section{Claus Emmeche}

Center for the Philosophy of Nature and Science Studies, Niels Bohr Institute Blegdamsvej 17, DK-2100 Copenhagen, Denmark e-mail: emmeche@nbi.dk

\begin{abstract}
A central aspect of the relation between biosemiotics and biology is investigated by asking: Is a biological concept of function intrinsically related to a biosemiotic concept of sign action, and vice versa? A biological notion of function (as some process or part that serves some purpose in the context of maintenance and reproduction of the whole organism) is discussed in the light of the attempt to provide an understanding of life processes as being of a semiotic nature, i.e., constituted by sign actions. Does signification and communication in biology (e.g., intracellular communication) always presuppose an organism with distinct semiotic or quasi-semiotic functions? And, symmetrically, is it the case that functional relations are simply not conceivable without living sign action? The present note is just an introduction to a project aiming at elucidating the relations between biofunction and biosemiosis.
\end{abstract}

Biology has celebrated some major triumphs in the period beginning with Darwin's publication of Origin of Species in 1859 all the way up to 2001, when newspaper headlines proclaimed that the human genome had now been charted. Now that biology has shown us what life is (from a scientific standpoint), what shall we do with biosemiotics?

The biosemiotic project involves looking from a completely different angle at natural biological processes of which, to be sure, we have already gained knowledge about through the traditional science of biology and the research fields it includes (molecular biology, cellular 
biology, ethology, ecology, neo-Darwinian evolutionary theory, etc.). From these disciplines, we have now gained an enormous amount of knowledge of living organisms. At the same time, however, there are gaping holes in this knowledge. It has a dual nature, i.e. on the one hand it comprises a large body of positive facts and theoretical generalizations, even coherent and well-confirmed theories (such as cellular theory and evolutionary theory), but on the other hand it takes the form of non-knowledge. The latter applies, in particular, to the knowledge we have gained of humans as a species by mapping the human genome. This non-knowledge exists at least at two levels.

First of all, there is non-knowledge in the form of holes or white blots on the previously existing theoretical map of biological fields that may be filled in, possibly in the near future. The hope is that more research funds and research hours will be able to fill these holes. Obviously, for example, now that we have the complete human genome $^{1}$ we would also like to map out the complete chimpanzee genome, since the chimpanzee is our nearest biological relative and we hope to gain a better understanding of that kinship. All we need to do is begin the task of DNA sequencing a chimpanzee - a major undertaking, to be sure, but one that is fully feasible. In this way, we can continue doing the same with other species. Even today, we have detailed genetic maps of biologists' favorite model organisms (the fruit fly, a nematode worm, the coli bacteria, the yeast cell, and even, in part, the mouse).

Secondly, our biological non-knowledge exists at a level on which we are approaching the limits of what we can expect to know if we simply use existing methods with no breakdown in our theories, i.e. if we simply continue placing more small pieces into the existing puzzle. With regard to certain questions, if non-knowledge at this level were transformed into knowledge, we would probably need to look at them through different theoretical glasses or use a different paradigm, in the precise sense Thomas Kuhn uses this word. Here, a paradigm is not just another theory that may assign a slightly different meaning to the concepts that were previously used, but almost another world, at least

${ }^{1}$ The news in 2001 that the human genome has now been charted should be taken with a grain of salt, since the picture is hardly complete. Rather, there is a complete collection of sketches, although they are highly detailed. For the technical details, see Nature 409: 745-964 (15 February 2001), a large issue devoted to this topic including, among other things, the preliminary collection of sketches. 
for the researcher, i.e., a different set of theoretical tasks, some different values used to determine what constitutes good questions and even for which things a person, as a scientist, can research in the first place. It is on this latter level, in particular, that biosemiotics tackles the problem, using the following fundamental assertion: The traditional paradigm in biology - which encompasses a number of experimental methods, normal scientific working procedures, neoDarwinism and its mathematical population models, etc. - alone is not and cannot be sufficient to answer the following key question: ${ }^{2}$ How did meaning originate in biological systems? And what is it (if not meaning, i.e. the creation of signs, and semiotic processes in general) that makes biology something special, something that on certain points fundamentally differs from the types of systems studied, for example, by physicists and chemists?

Here we shall undertake a thorough examination of the idea of the biological creation of meaning as something central to all living things by taking a closer look at the way in which people normally answer the riddle of what it is about organisms that is special, i.e., we will look at the answer provided by "mainstream" biologists or conventional anti-reductionist biologists such as Ernst Mayr (who did not like to see his field, evolutionary biology, reduced to chemistry as applied to biology) and compare it to the answer given by leading biosemioticians, in the tradition from Jakob and Thure von Uexküll and Thomas A. Sebeok up to biosemioticians such as Jesper Hoffmeyer and Kalevi Kull. Let us reveal right away that traditional biological understanding ${ }^{3}$ mentions two crucial characteristics of living systems that make them radically different and irreducible to physics and chemistry:

\footnotetext{
2 Jesper Hoffmeyer's 1996 book (which was discussed in detail in the journal Semiotica 120(3/4) (1998), and is a good introduction to biosemiotics) asks this question most clearly. A Danish introduction focusing on the status of scientific theory in biosemiotics is Emmeche 1997. K. Kull (1999) provides a historical overview of the more recent ideological history of biosemiotics.

This includes, for example, John Maynard Smith, who has made significant contributions to evolutionary theory. See, for example, Maynard Smith (1986, 1999a, 1999b). The 1999a article attempts to "explain" information functionally. This is not the place to discuss why the classical attempts to reduce functional descriptions in the place to discuss why the classical attempts to reduce functional descriptions in
biology have failed. An introduction to the discussion can be found in Schaffner biology have failed. An introduction to the discussion can be found in Schaffner
(1993). Maynard Smith's 1999b article contains a rather lengthy analysis and subsequent discussion that would lend itself well to semiotic treatment.
} 
(1) biosystems (organisms) contain genetic information;

(2) biosystems (organisms) have functions.

The former, of course, is a cryptosemiotic concept, for even here biologists admit indirectly that it is necessary to use semiotic concepts to describe biological systems. It is just that biologists do not attribute any particular significance to this: after all, they typically say, "genetic information" is just a metaphor for certain molecular processes that are organized in a certain way. Here the biosemiotician steps in and interprets the occurrence of such metaphors more realistically, namely as a sign that when one apparently cannot understand a key biological process, such as the hereditary transfer of traits between generations, without having to use informational metaphors, it is probably because the processes themselves, for which the metaphors are meaningfully used, actually have the nature of semiotic processes - sign production, sign transfer, and sign interpretation. ${ }^{4}$

As we know, the second point - that organisms have functions is particularly well known in biology. No biologist can get by without directly or indirectly referring to the (functional) role some part or another of the organism plays in the whole organism. ${ }^{5}$ On the other hand, many philosophers and some theoretical biologists, such as John Maynard Smith, have speculated that this all-pervasive interest in functions is what makes biology different from the science that deals with inorganic nature, such as those branches of basic physics that only study physical processes.

But do we not run into the concept of function here, too, one might ask? Certainly it is not complete nonsense to ask what function solar wind has for the earth's atmosphere? The standard response here is that the question is understandable, to be sure, in so far as it can be reworded into a question of the causal role a phenomenon such as solar wind can conceivably have on earth's atmosphere as a physical system, but to the extent that it can be answered as such - purely physically causal - there are nonetheless some significant differences between the limited role the concept of function can play in a subject

${ }^{4}$ I have programmatically described (as a philosophical position) this semiotic realism, which such an interpretation expresses, as the opposite of what today would be called a more social-constructivist interpretation (Emmeche 1988, 1990).

5 A classical text on the concept of function that is close to the standard understanding among biologists was written by the evolutionary biologist F. Ayala (1970). 
such as geophysics or astrophysics and the key role it plays in biology. Of course, the difference is so great it is really just a matter of using the same term for two different concepts. In physics the assertion or question of function (such as the one mentioned above) can be rewritten without loss of meaning to the purely causal ${ }^{6}$ question of direct cause-and-effect contexts in the traditional classical mechanical sense, in which a cause precedes an effect in time, but both cause and effect exist on the same ontological level, i.e., they are of the same nature, as in the example of the relationship between the sun and the earth's climate. This is a matter of material physical processes on the macroscale. As shown by the past 30 years of discussions on the concept of function in the philosophy of biology ${ }^{7}$ it is far more complex to state the connection between causality and functionality in biology.

Essentially, the reason for this difficulty is that in biological systems there is an inner connection between the informational (which, without hesitation, we will call here the semiotic aspect of a living system) and the functional aspect. This is a connection that has been largely overlooked in the past and we will examine it in greater detail now.

Traditional biologists know quite well, implicitly at least, that there is a connection between the functional and the informational aspect: No organism exists that does not consist of a whole of its parts, whereby the parts enter into functional relations with one another and with the whole. Even in the simplest conceivable organism, such as a simple, free-living cell, this is dependent on the cell's organizing its parts, not exclusively but in part with the help of a genetic memory (a semiotic code), which makes sure the (functionally) "correct" parts are produced in the cell's autocatalytic network of processes. In this case, it is primarily protein synthesis, whereby without the genetic memory a mere jumble of "dysfunctional" proteins that are useless to the cell would be produced.

${ }^{6}$ Most often, as here, "purely causal" questions are considered to deal with the kind of causal context that is most closely related to "effective causality" as Aristotle understood it, for example when the cause of the collapse of a wall is said to be the energy from the steel ball suspended from the crane. The fact that there is also an energy from the steel ball suspended from the crane. The fact that there is also an
ultimate or purposeful cause - namely that the wall is to be removed to make room for something else - is typically considered secondary.

or something else - is typically considered secondary.
${ }_{7}$ A recent survey of the debate is presented by the editors of the 1998 anthology in which Ayala 1970 is reprinted. 
As we know, from a chemical standpoint proteins are a rather normal kind of large molecule (polymers characterized by peptide bonds, which combine the individual building blocks, amino acids, into long chains). It is one thing, as a chemist, to use chemical theory and experimentation to identify a molecule as a protein, and not a sugar, a lipid, a nucleic acid, or something else. But it is something quite different, as a biologist, to characterize a particular protein as an enzyme, or a neuropeptide, or a hormone, or a histone (which is a class of proteins involved, among other things, in the packing of chromosomes $).{ }^{8}$ If it is found that a protein is a histone or an enzyme, for example, then this is also, in part, a functional description of the protein. It says something about the relationship between part (protein) and whole (the cell as an organism). This is rather banal, as far as it goes, and on the concrete level of molecular biology it is nothing new, but the semiotic and biotheoretical implications of this fact are far-reaching:

As we shall now show, this means that function and sign, both seen biosemiotically as phenomena that describe living organisms, are directly related to each other, even in the narrow sense, i.e. both ontologically and epistemologically, or in other words: both as (ontological) properties of nature and (epistemologically) as conditions for our knowledge of nature.

Ontologically, sign and function are related like the chicken and the egg: It is a bit absurd to ask which came first, the sign in nature or functions in nature: biosemiotically, both arise simultaneously in the same lengthy historical process, with the creation of the first

8 "As a biologist", i.e. by virtue of biological knowledge and competence. Obviously, chemists are not excluded from biology or from speaking of functions in a biological sense when they describe the function of an enzyme in a metabolic pathway ("reaction step"), but when they do so, they are doing it on the basis of biological concepts and in the capacity of biologists. Against this argument (concerning the concepts and in the capacity of biologists. Against this argument (concerning the
difference between a chemical and a biological description of a molecule) one might object that in practical research, for example in molecular biology and its biotechnological applications, there is no sharp distinction between when a one is a chemist and when one is a biologist. This is absolutely correct, but the fact that the methods of chemistry and biology are used together here in this interdisciplinary field does not mean that the meaning of any biological concept can be derived, so to speak, from chemical theory. The fact that chemistry and biology have gone a relatively long way toward epistemic integration precisely in the field of molecular biology (cf. Collin 1990), does not necessarily mean that the chemical and the biological domains are the same, ontologically speaking. 
organisms, which of course have cellular structures, here on earth at least. Of course, a stolid biologist could choose to interpret the chicken/egg duality in the light of the biological difference between a single-celled and a multicelled organism. In this case, the question of the chicken and the egg is not quite so absurd: In this case, from the phylogenetic perspective, it is namely the egg that "came first", since we must assume that multicelled organisms ("individuals") are a (not uncomplicated) product of a long evolutionary process (cf. Buss 1987). But the evolutionary sequence of single-celled and multicelled organisms is not the point here at all. The point is, 1): that in our basic understanding of what living beings are, we must operate with a concept of the organism that presupposes that the organism is both a semiotic phenomenon - a system of sign processes - and a functional phenomenon - a whole made of parts, where the parts have functions relative to one another and relative to the maintenance of the whole, and 2): that these two aspects, the mereological ${ }^{9}$ and the semiotic, are closely linked.

With regard to the organism, as understood not just as a concept, but as a real ontological entity, the mutual functional relationships of the organism are semiotic. ${ }^{10}$ For now, let us stick to single-celled organisms and look at a part of the cell, such as an enzyme. It has a function of catalyzing a chemical process, let us say, between two other molecules (there can be many other enzymatic functions, such as

${ }^{9}$ Mereology: the study of parts and wholes, usually refers to a mathematical or at least formal theory thereof, such as that of Lesniewski or Goodman; developed by the former in the hope of forming an alternative to set theory as a foundation for mathematics. For the relationship between mereology and semiotics, see Stjernfelt (2000), although he does not deal specifically with the biosemiotic aspects.

${ }^{10}$ One might well ask what knowledge we are actually expressing when we claim that the relationships between $\mathrm{x}_{1}, \mathrm{x}_{2}, \ldots \mathrm{x}_{\mathrm{n}}$ as parts of a system $Y$ are "semiotic". What characterizes the non-semiotic relationships of something if we have otherwise adopted an almost pansemiotic Peirce-inspired perspective? However, we would be going too an almost pansemiotic Peirce-inspired perspective? However, we would be going too
far here if we took up the question of a "lower semiotic threshold" (which has been dealt with in Nöth 2000a, 2000b, and elsewhere); it is sufficient to state that even a Peirce-based semiotics need not be pansemiotic (and maintain that any conceivable or real relationship in itself has the nature of a sign). For example, purely dyadic relationships, which occur in physical processes, have the category of "secondness" (sensu Peirce), such as action and reaction. Such processes can be called kinesis, as opposed to semiosis, which is of the category of thirdness: a living organism is subject opposed to semiosis, which is of the category of thirdness: a living organism is subject
to the kinesis of the physical laws of nature, but as an organism it can be understood only as a phenomenon of thirdness, i.e. as a semiotic phenomenon that is dependent on active signs, "sign action", sign production, and sign interpretation (Emmeche 1991). 
breaking down molecules into smaller parts, but that is secondary here). Of interest here is not the enzyme as chemistry (for example, its structural formula seen in isolation or its three-dimensional structure seen in isolation), but the circumstance that when the enzyme is found in a cell with such and such other molecules, then it "acts" in such and such a way, i.e., it reacts with these molecules, thereby acquiring meaning to the cell (in this case: to reduce the activation energy required to establish a bond, for example, between two other molecules that are substrates for the active site on the enzyme, thereby increasing the rate of the process). ${ }^{11}$ In other words, using the enzyme cytochrome $c$ as an example, the function of this enzyme is the same as the cell's "structural attribution of biological meaning" to the cytochrome c molecule.

What does this have to do with meaning, one might ask? After all, it is we who can see that it has meaning (functionality) to the cell. Certainly the cell itself cannot understand that? Correct, but we will avoid the nominalistic temptation of seeing signs only as something that can be of a mental nature (signs in human language or understanding). Although the cell does not realize, perceive, or understand anything, the cell is still a semiotic system in the sense that it is a

${ }^{11}$ This 'when $X$, then $Y$ ' form is reminiscent of both 'if ... then' in logical inference and 'if ... then' conditions expressed in connection with physical laws of motion. One might believe, then, that there is no difference between physical laws of nature expressed as regularities of the form "If a body is dropped above the earth it falls to earth with a uniform acceleration" (Galileo's Law of falling bodies) and the causality found in the functional relationship in the organism between part and whole, if both are found in the functional relationship in the organism between part and whole, if both are
merely regularities that can be expressed as 'if ... then' conditions. However, this empirical interpretation of natural law has been greatly criticized, for example by a (Popper-inspired) 'propensity' interpretation, which does not hesitate to attribute to nature forces, capacities, dispositions, etc. See Chalmers' discussion in Chapter 14 of the new 3rd edition of his theory of science. What Chalmers forgets is that the generality of these dispositions (etc.), which are attributed to the individual particles or objects, is better understood on the basis of Peirce's ontology, where generalities and forms (including process forms) are real properties inherent in nature: they are "habits". (I am grateful to Peder Voetmann Christiansen for introducing me to this aspect of Peirce's philosophy). But even though the physical nature can generally have habits and be regularly controlled by "final causation", it is nonetheless a rather special form of final causation that occurs in organisms, which is related to the history-ofsymbols nature of the genetic memory in the species' lineage: DNA acts here as a boundary condition (Polanyi 1972), life is complex because these boundary conditions are historical (cf. Küppers 1992), and from a semiotic standpoint we could add that such boundary conditions or "constraints" are phenomena that have all the characteristics of being causes (Juarrero 1998). 
system of meaning with its own autonomous self-catalysing, selforganising dynamic - a dynamic, as mentioned above, that is so complex as to presuppose genetic memory as a sign system. But the important thing here is not so much the latter digital and relatively stable DNA code found in the cell's nucleus in eukaryotic organisms, as it is the sign processes of a far more general kind: Saying that cytochrome $c$ means something to the cell is the same as saying that it has a function. It is not just any molecule. We could very well synthesize small proteins and artificially introduce them into the cell. They would be without importance or they would be dysfunctional or, with certain fortuitous strokes of luck, they would actually fulfil some function in the cell.

To say that cytochrome $c$ or any other molecule fulfils a function for the cell as an organism (or for multicellular organisms: an organ, or an organ part that fulfils a function) is the same as saying that the part operates appropriately in the whole (an idea entertained by Kant). It is the whole, with its special emergent structure, that establishes the framework for this appropriateness and even though the basic laws of nature are still in effect ("effective", or "brute causation"), it is the cell as a complex system that manages or shapes the manner in which the natural laws operate on the individual parts: the whole operates as a constraint, as a limiting condition from the macro level down to the micro level, from the whole to the part.

The protein cytochrome $c$ is specific and the biological specificity is precisely the difference cytochrome $c$ makes to the cell. After all, if cytochrome $c$ had not had precisely this particular form (at least in its active sites), it would not bring about the reaction between the components with which it interacts. It would be dysfunctional (as it can become if the gene for cytochrome $c$ mutates, which can be fatal to the cell). ${ }^{12}$ Cytochrome $c$ mediates precisely this reaction and not all kinds of other ones - therein lies its meaning. This "meaning", in the semiotic sense, of the individual enzyme is structural, understood in such a way that the cell's molecules form a system of dissimilarities

${ }^{12}$ More precisely, cytochrome $\mathrm{c}$ functions as one of the important electron transporters in the respiratory chain, which (by oxidative phosphorylation) produces the main part of the energy-rich ATP, which is so important to the cell. This is an important and general function, as a result of which the overall structure of the cytochromes is evolutionarily conserved across species, from bacteria to elephants. 
(like the elements of language in Saussure ${ }^{13}$ ), but these dissimilarities are not of a mental or immaterial kind. The material elements of the system have a certain agency ${ }^{14}$ of their own, or a local semiotic capacity to act, if you will, and consequently the cell's molecular system of signs is self-organizing and self-interpreting, i.e., these signs are characterized better by the Peircean concept of sign as sign action than by the Saussurean concept of sign as an abstract system of differences. To a great extent, the cell is an interpretation system that is controlled by what Peirce called "final causation", the type of causation in nature that has to do with organization, habit formation, memory phenomena, information, appropriateness and purposefulness, evolution - all phenomena of the category of Thirdness (Santaella Braga 1999). ${ }^{15}$

But epistemologically, too, there are close mutual conceptual conditional relations between sign and function, at least within the framework of a Peirce-inspired biosemiotics: The assertion here is that it is simply impossible to understand the concept of sign, without a concept of function (of some kind or another). And, as just indicated, the inverse is also true: It is not possible to understand the concept of function in biology in general without a good understanding of what an organism is and such an understanding presupposes a concept of information, whether it be in the slightly superficial molecular biology version as (DNA-) sequence information or in a more thoroughly thought-out Peircean version, where information is sign. As Bateson (1972) said, "information is a difference that makes a difference" ("to an organism" implied) and this is 'straight Peirce', even though he probably would have stated it in a more complex, but more precise, form such as "sign (representamen) is a difference that makes a difference (interpretant) by making the latter stand in relation to something else, namely that to which the sign refers (object)". We might add:

${ }^{13}$ For a detailed treatment of the relationship between Peirce and Saussure as a basis for biosemiotics, see Emmeche, Hoffmeyer 1991.

${ }^{14}$ This agency or "energy" is an indication that the material itself is active. With regard to proteins it is dictated, among other things, by thermodynamic processes in the protein's molecular self assembly, after the protein is synthesized as a long peptide chain and folds itself together into what resembles a ball of yarn, for example, although it is helped in part by other proteins, particularly the chaperones.

${ }^{15}$ The same volume of Semiotica $127(1 / 4)$ is a special edition on this theme, with
The numerous articles on biosemiotics, including another contribution by L. Santaella Braga on Peirce and biology, then and now. 
"Function is the difference that the presence of a part of the organism makes with respect to other parts and to the whole".

The part refers to the whole and can be understood (functionally) only within this whole. That is an old mereological insight. When we recognize cytochrome $c$ as a part of the organism, we are not just interested in a recognition of this protein as a part, similar to the recognition that a stone is part of a gravel heap or that $1 / 7$ is a part of the rational numbers. It is not the abstract part-whole relationship in itself or a physical version of such a relationship that is crucial here. The crux of the matter here is that the relationship between the parts of an organism and the whole organism is a mereological relationship of a particular specific nature: It is also an "intrinsic semiotic relationship", that is, it is in its very nature semiotic. And, it should be noted, its semiotic character is not merely something attributed to it, just as our consciousness is not just due to the fact that other people attribute consciousness to me, but I am actually conscious and it is part of the concept's sine qua non that being conscious is not derived from anything else. ${ }^{16}$ Apart from this formal similarity, the intrinsic semiotics of the cell has nothing to do with consciousness in the human sense.

We now realize that there must be an internal relationship between sign and function, that is to say when the two concepts are used in conjunction with organisms and with what are essential features of organisms. ${ }^{17}$ We have also more than hinted at what is meant by internal relationship, but let us express it a bit more formally. In the philosophical usage of the term, if something, let us call it $S$, is internally related to something else, let us say $F$, then there is an essential property (a sine qua non) of $S$ whereby $S$ is actually linked to

${ }^{16}$ It should be mentioned that not all philosophers agree with this: there is an important line of demarcation in modern philosophy of mind between those who believe that consciousness is an intrinsic property (such as Searle and Nagel) and those who more or less behaviouristically try to explain consciousness under the designation who more or less behaviouristically try to expla
"the intentional stance", etc. (such as Dennett).

${ }^{17}$ It is not our intention here to discuss essentialism, but the framework of evolutionary history assumed here, in itself, places certain limitations on a "full blown" essentialism. Essentialism in biology refers to the now abandoned idea that the properties of an organism are of two essentially different types: the essential, which defines for example whether the organism belongs to the species red clover or white defines for example whether the organism belongs to the species red clover or white
clover, and the accidental, which does not have quite the same nature of reality. clover, and the accidental, which does not have quite the same nature of reality.
Darwinism disposed of essentialism, for it saw all properties as possessing the same degree of reality, and variation was not just something accidental and negligible, but the very material on which selection operated. 
$F$ by this relationship, symbolized here by $-R$ - Thus, $S$ simply would not be $S$, if it were not related to $F$ in this manner, i.e. if $S-R-F$ were not valid. Specifically, it would mean that a sign would not be a sign (in the biosemiotic sense) if it were not a sign with a function, which normally means "with a function for the organism". The traditional biologist could accept this part of the argument, since it is hardly surprising that a process involving information, signals, or signs in an organism must serve the best interests of the organism, i.e. it must be functional for the organism.

At the same time, however, we would maintain that the relationship is symmetrical, i.e. if $S-R-F$ is valid then so is $F-R-S$, or in plain language, if sign is internally related to function, then function is also internally related to sign. A thing would simply not be a function (for the organism) if it did not have the nature of a sign. Stated in this way, the assertion does not appear to be immediately obvious to the traditional biological viewpoint, since it is easy to imagine certain functional parts of an organism, without their obviously being signs and, as mentioned, biologists do not normally use semiotics as a conceptual tool. What does it mean, for example, to say that the liver of a vertebrate animal is a sign? - "Of what?" one might sceptically ask. And what have we gained by such an assertion?

Or, with an example from the single-celled level: The Golgi apparatus in eukaryotic cells, as seen under the electron microscope, looks like a stack of flat bladders (membranes) stacked one on top of the other. There are still some dark sides regarding the function of this structure, but a picture has developed ${ }^{18}$ of a membrane structure that is linked to the rest of the cell's transport system, a kind of halfway house between the endoplasmic reticulum, where proteins are synthesized, and the secretory vesicles, which (in the periphery of the cytoplasm, at the outer membrane of the cell) take proteins out of the cell by means of exocytosis (membrane fusion). In addition to being part of the transport system, the Golgi apparatus performs a biochemical modification of the proteins that are on their way out into the surroundings (for example, "ripening" of glycoproteins by removing certain oligosaccharides and adding others). Thus, the Golgi apparatus clearly has functions for the cell, but why would this make it a sign?

${ }^{18}$ More details can be found, for example, in Alberts et al. 1994. 
Here, the biosemiotician must either sacrifice the idea of the internal relationship, in its strong, symmetric form, which means that not all biofunctions are or can be interpreted by us as being real signs, or the biosemioticean can hold onto the symmetry; protest that we should not use an all-too narrow concept of sign, and instead interpret the relationship as follows: If a relationship is merely dyadic, or merely comprised of dyadic relationships, as indicated by the notation $F-R-S$ then, to be sure, the relationship need not have the nature of a sign. But if $F$ and $S$ do not stand for just anything, but for function and sign, and if, in conjunction with organisms, function is already a mereologic relationship, then $F-R-S$ will not formally be a dyadic, but rather a triadic quantity: Any biofunction is something (a process or a structure) that has meaning for the organism as an interpretant system (what theoretical biologist Stanley N. Salthe and others call a "system of interpretance" ${ }^{\text {"19 }}$ ), and in this broad meaning of the statement $F-R-S$ any functional process or structure in a cell is "biologically meaningful", in that it makes a difference to the cell as a whole, as a system, that would be affected immediately (often in a rather fatal direction) if the process were blocked or the structure destroyed. Thus, the Golgi apparatus and everything at all we can understand in a biofunctional sense has the nature of a sign, where "sign" need not be a communicative sign in the normal sense, but may instead be purposeful processes, with the special causal structure these processes have.

But even if biofunctions may be said to have the nature of signs, is it not crazy to claim that the Golgi apparatus is a sign that (according to the classical definition of sign) "stands for" something else? Yes and no. This "stands for" relationship is obviously not a symbolic or conventional relationship, but as we know there are also sign process forms other than the symbolic. As mentioned, the Golgi apparatus (if it is to be understood at all biologically and not just described physically and chemically) refers to other structures in the cell and here it is the assertion of biosemiotics that this reference relationship is triadic. The shape of the Golgi apparatus and the processes that occur in it are not of importance to the endoplasmic reticulum and the exocytotic vesicles alone. They are important to the cell as a whole. The mereological relationship is not just formal, but also causal,

${ }^{19}$ Even though Salthe (1998:391) has a broader (physicosemiotic) understanding of what can comprise a "system of interpretance" than the biosemioticist, the term is applicable here. See also the overview on his homepage at www.nbi.dk/ natphil/salthe/ 
namely a case of what in some contexts is called "downward causation". ${ }^{20}$ It is the whole that "assigns" meaning to the parts. Just as a protein is an enzyme only when it works within a meaningful whole, the same is true of the Golgi apparatus. Seen in itself, as a "pure" spatial structure, it could just as well have been an accidental pattern in nature or a bizarre sculpture on the nanoscale (nanoart!). But it is the organization of the cell as such that co-defines the boundary conditions under which the Golgi apparatus operates. It is part of the cell's quasi-cognitive scheme of protein synthesis and transport. It may have a diagrammatic character (which must be the subject of a more detailed semiotic analysis at a later time).

Such a biosemiotic understanding of the concept of function can also include cases in which the function is not yet known: The sequences of DNA (genes) that code for proteins or RNA molecules are easily seen as having the nature of signs, but what about the noncoding parts, such as the repetitive sequences (whose function is not known) or other parts of the so-called junk DNA which, as we know, forms the bulk of our genome? In this case, the function is not known and one might believe that the assertion concerning the internal relationship between function and sign applies only to those parts of the organism or cell where the function is known. However, the sequences mentioned above can be seen as instances, sinsigns, ${ }^{21}$ of the same type, legisign, i.e. they are sequences of the same pieces of noncoding DNA found in the previous generation. The way in which DNA is copied (template replication) assures the preservation of the sequence information and, thus, a simple sinsign/legisign relationship (just as a cookie cutter as a general type imparts its shape on each individual cookie instance). This is important to the relationship of general interest that organisms are internally related to one another through bonds of kinship. For example, I am related to my parents, since I would not be me if I did not have precisely those parents.

\footnotetext{
${ }^{20}$ See Emmeche et al. 2000.

${ }^{21}$ The first of the three trichotomies in Peirce's 10-sign classification is division according to the sign's own character; whether it is a quality in itself (qualisign), an actual, existing individual thing or individual event that is a sign (sinsign), or a sign of a general type of such individual events or things (legisign). For example, the individual " $\mathrm{A}$ " is a sinsign of the general type (legisign) A.
} 
A person who was apparently identical to me but had other parents would not really be me. ${ }^{22}$

But does everything in the cell have the nature of a sign? This may seem a bit hard to swallow for traditional thinking but to the extent that we can, first of all, stick to the biosemiotics of living organisms and not discuss the possibilities of sign processes in physical nature physicosemiosis ${ }^{23}$ - and, secondly, identify in organisms the triadic relationships and interpret them as instances of the abstract semiotic relationships and processes, which Peircean semiotics conceptualises, the answer must be "yes".

One clever person has said that the chicken is simply the egg's way of creating a new egg and there has been no shortage of sociobiological elucidations of this bit of wisdom. The egg as the active and acting, that which uses something else as a functional tool. Or the egg as the original, as in the elucidation of stolid evolutionary biology we saw earlier. ${ }^{24}$ But any child knows that chickens and eggs belong together, in the same temporally continuing process, whose detailed embryological sign functions molecular biologists are still working to map out.

Life itself arises from the physical, but it cannot be fully explained by the physical from which it has arisen. The ancient Phoenicians, Egyptians, Hindus, Japanese, and others believed the world was eggshaped and that the world as we know it was hatched from an egg laid by the creator. ${ }^{25}$ In some myths, including one attributed to Orpheus, a bird is seen as the one that lays the mundane egg in the primordial sea. If we assume that Orpheus actually existed, then as a poet he certainly refrained from asking whether that bird itself had hatched from some egg. Modern science, too, refrains from asking certain questions. But perhaps we cannot completely let go of the Orphean egg. When it comes to fundamental problems in modern biology and natural science as well as in general semiotics, there are always some things that simply have to be assumed and that refer to one another.

\footnotetext{
${ }^{22}$ This example is taken from Wagner 1999.

${ }^{23}$ See, for example, Deely 1990, Salthe 1998, or Christiansen 1988.

${ }^{24} \mathrm{Or}$, as an extension of this: the egg as a part of the code duality, which must be described in relation to a lineage of organisms within the same species. See Hoffmeyer

25 "Egg, the mundane egg" in E. C. Brewer (rev. by I. H. Evans): The Wordsworth Dictionary of Phrase and Fable [1959], 1970, 1994, published by Cassell \& Co.
} 1996. 
Organisms are always pivotal. The Orphean egg is laid by a bird - it makes a splash, and slowly the dust begins to lift a bit. ${ }^{26}$

\section{References}

Alberts, Bruce; Bray, Dennis; Lewis, Julian; Raff, Martin; Roberts, Keith; Watson, James D. 1994. Molecular Biology of the Cell. New York: Garland Publ.

Ayala, Francisco J. 1970. Teleological explanations in evolutionary biology. Philosophy of Science 37: 1-15. (Reprinted in: Allen, Colin; Bekoff, Marc; Lauder, Georg (eds.) 1998. Nature's Purposes: Analysis of Function and Design in Biology. Cambridge: The MIT Press, 29-49.)

Bateson, Gregory 1972. Steps to an Ecology of Mind. New York: Ballantine Books.

Buss, Leo W. 1987. The Evolution of Individuality. Princeton: Princeton University Press.

Chalmers, A. F. 1999. What is this Thing Called Science. 3rd ed. Buckingham: Open University Press.

Christiansen, Peder Voetmann 1988. Introduktion. In: Peirce, Charles S., Mursten og Mortel til en Metafysik. Fem artikler fra tidsskriftet "The Monist", 189193. (Tekst nr. 169 fra IMFUFA.) Roskilde: Roskilde Universitetscenter, 6-66.

Collin, Finn 1990. Videnskabsfilosofi: Enhed og mangfoldighed $i$ videnskaberne. København: Museum Tusculanums Forlag.

Deely, John 1990. Basics of Semiotics. Bloomington: Indiana University Press.

Emmeche, Claus 1988. Den anden natur og naturens tegn [Second nature and the signs of nature]. In: Christensen, Jens (ed.), Natur og moral. (Arbejdspapirer fra NSU nr. 27.) Aalborg: Nordisk Sommeruniversitet, 67-91.

- 1990. Det biologiske Informationsbegreb. Århus: Kimære.

- 1991. A semiotical reflection on biology, living signs and artificial life. Biology and Philosophy 6(3): 325-340.

- 1997. Den biosemiotiske tanke. In: Jørgensen, Keld Gall (ed.), Anvendt Semiotik. København: Gyldendal, 62-94.

Emmeche, Claus; Hoffmeyer, Jesper 1991. From language to nature - the semiotic metaphor in biology. Semiotica 84(1/2): 1-42.

Emmeche, Claus; Køppe, Simo; Stjernfelt, Frederik 2000. Levels, emergence, and three versions of downward causation. In: Andersen, Peter Bøgh; Emmeche, Claus; Finnemann, Niels Ole; Christiansen, Peder Voetmann (eds.), Downward Causation: Minds, Bodies and Matter. Aarhus: Aarhus University Press, $13-34$.

${ }^{26}$ Acknowledgements. The author would like to thank Thorkild Thellefsen and Iben Sletten for for their useful comments on a Danish version of the manuscript. Thanks also to Jesper Hoffmeyer, Frederik Stjernfelt, and Simo Køppe for numerous discussions over a long period of time, among other things on the concepts of function and sign. 
Hoffmeyer, Jesper 1996. Signs of Meaning in the Universe. Bloomington: Indiana University Press.

Juarrero, Alicia 1998. Causality as constraint. In: Vijver, Gertrudis Van de; Salthe, Stanley N.; Delpos, Manuela (eds.), Evolutionary Systems: Biological and Epistemological Perspectives on Selection and Self-organization. Dordrecht: Kluwer, 233-242.

Kull, Kalevi 1999. Biosemiotics in the twentieth century: A view from biology. Semiotica 127(1/4): 385-414.

Küppers, Bernd-Olaf 1992. Understanding complexity. In: Beckermann, Ansgar; Flohr, Hans; Kim, Jaegwon (eds.), Emergence or Reduction? Essays on the Prospects of Nonreductive Physicalism. Berlin: Walter de Gruyter, 241-256.

Kuhn, Thomas S. 1970 [1962]. The Structure of Scientific Revolutions. (2nd. ed.) Chicago: The University of Chicago Press.

Maynard Smith, John 1986. The Problems of Biology. Oxford: Oxford University Press.

- 1999a. The idea of information in biology. Quarterly Review of Biology 74(4): 395-400.

- 1999b. The concept of information in biology. Philosophy of Science 67: 177194 [with commentaries from Kim Sterelny, p. 195-201, Peter Godfrey-Smith p. 202-207, Sahotra Sarkar p. 208-213, and a reply from Maynard Smith p. 214-218].

Nöth, Winfried 2000a. Umberto Eco's semiotic threshold. Sign Systems Studies 28: 49-61.

- 2000b. Handbuch der Semiotik. (2te Auflage.) Stuttgart: Verlag J. B. Metzler.

Polanyi, Michael 1968. Life's irreducible structure. Science 160: 1308-1312.

Salthe, Stanley N. 1998. Naturalizing semiotics. Semiotica 120(3/4): 381-394.

Santaella Braga, Lucia 1999. A new causality for understanding the living. Semiotica 127(1/4): 497-519.

Schaffner, Kenneth F. 1993: Discovery and Explanation in Biology and Medicine. Chicago: University of Chicago Press.

Stjernfelt, Frederik 2000: Mereology and semiotics. Sign Systems Studies 28: 7298.

Wagner, Steven J. 1999. Relation. In: Audi, Robert (ed.), The Cambridge Dictionary of Philosophy. Cambridge: Cambridge University Press, 788-789.

\section{Курица и яйцо Орфея:}

\section{о функции значения и о значении функции}

При исследовании связей между биосемиотикой и биологией центральным является вопрос: связаны ли внутренне биологическая концепция функции и биосемиотическая концепция действий знака? В статье биологическая функция (как процесс или его часть, которая имеет 
определенную цель по отношению к деятельности и самопроизводству организма как целого) анализируется в связи с пониманием семиотического (проявляюшегося в знаковых действиях) характера жизненных процессов. Предполагают ли сигнификация и коммуникация в биологии (например внутриклеточная коммуникация) всегда какой-либо организм вместе с его отдельными семиотическими или квазисемиотическими функциями? И наоборот, разве нельзя даже помыслить функциональные отношения без живого действия знаков? Настояшая работа, являясь лишь введением к более широкой теме, ставит своей целью разъяснение взаимоотношения между биофункциями и биосемиозисом.

\section{Kana ja Orpheuse muna:}

\section{tähenduse funktsioonist ja funktsiooni tähendusest}

Uurides biosemiootika ja bioloogia vahelisi suhteid on keskse aspektina küsitud: kas bioloogiline funktsiooni kontseptsioon on seesmiselt seotud biosemiootilise arusaamaga märgi toimimisest, ja vastupidi. Artiklis analüüsitakse bioloogilist funktsiooni (kui protsessi või osa, mis omab teatavat eesmärki organismi kui terviku toimimise ja taastootmise suhtes) seoses arusaamaga eluprotsesside semiootilisest (märkide toimimises avalduvast) loomusest. Kas tähendustamine ja kommunikatsioon bioloogias (näiteks rakusisene kommunikatsioon) eeldab alati organismi koos eraldiseisvate semiootiliste või kvaasisemiootiliste funktsioonidega? Ja kas, vastupidi, on nii, et funktsionaalsed suhted pole üldse mõeldavad ilma märkide elava toimimiseta? Käesolev töö on vaid sissejuhatuseks laiemasse teemasse, mis taotleb selgitada biofunktsioonide ja biosemioosi vahelisi suhteid. 